\title{
Investigation of Vocational Interest and Preference in Terms of Gender and Socio-economic Status
}

Kaan Zülfikar DENİ*

Ersin TÜRE**

Asl1 UYSAL ${ }^{* * *}$

Tuba AKAR ${ }^{* * * *}$

\section{Suggested Citation:}

Deniz, K. Z., Türe, E., Uysal, A., \& Akar, T. (2014).Investigation of vocational interest and vocational preference in terms of gender and socio-economic status. Eurasian Journal of Educational Research, 57, 91-112 http:/ /dx.doi.org/10.14689/ejer.2014.57.1

\begin{abstract}
Problem Statement: Individuals tend to prefer a vocation in order to reach their targets such as leading a life, nutrition, housing, being safe, having a good position in society etc. It is a task of the adolescence period to choose a vocation which is for some the most important step of the life, while for some others it is a rather important step in life however that can be changed and made flexible any time. All studies which are examined, show that vocational interest and vocational preference are affected by a great deal of variables.

Purpose of Study: In this study, the relations were investigated between the gender, socio-economic status (SES) variables and the vocational interest and the vocational preference.

Methods: Within this study, the long (OFII) and short form (OFII-SF) of the Occupational Field Interest Inventory were used. In total 812 students, who were studying at the preparatory classes of Ankara University $(\mathrm{N}=495)$ and Y1ldırım Beyazit University ( $\mathrm{N}=317)$ during the 2011/12 spring semester, took part in this study. Before the analyses were made, the raw scores obtained via OFII and OFII-SF were converted into z score.
\end{abstract}

${ }^{*}$ Corresponding author : Assist. Prof. Dr., Ankara University, Institute of Educational Sciences, Ankara, Turkey.zlfkrdnz@yahoo.com

${ }^{* *}$ Research Assist., Ankara University, Faculty of Educational Sciences, Ankara,

Turkey,.ersinture@gmail.com

${ }^{* *}$ Curriculum Specialist, B.Ü. Ayşeabla Private Schools, Ankara, Turkey. asli.uysl@gmail.com

**** Curriculum Specialist, Ankara University, Turkey. tubakoglu@gmail.com 
For the analysis of the data chi-square, independent samples $t$ test and one way ANOVA statistic techniques were used.

Findings and Results: At the end of the study, it was seen that there is significant difference with regard to the gender of the individuals in terms of the fields which they study and their interests. According to the findings that were obtained as per SES, it was found out that the departments of current higher-education and vocational interest (except for mathematics) of the individuals do not differ significantly.

Conclusions and Recommendations: It was found significant that the point differences with regard to OFII sub-dimensions are in favor of women for Psychology, Health, Law, Foreign Languages and Visual Art; in favor of men for Computer, Political and Financial Sciences, Engineering, Agriculture-outdoor and Physical Science. It can be asserted that these findings are in conformity with the gender-vocational interest studies. Many studies show that the interest/preference of the women for social vocations, which require working with people, is higher, while interest of men for the vocations which require working with objects and abstract concepts is higher. It was recommended, while measuring vocational interests that the gender variable is to be considered and new studies on SES variable carried out.

Keywords: Vocational interest, Gender, SES, Occupational Field Interest Inventory (OFII).

\section{Introduction}

Individuals tend to prefer a vocation in order to reach their targets such as leading a life, nutrition, housing, being safe, having a good position in society etc. It is a task of the adolescence period to choose a vocation which is for some the most important step of the life, while for some others it is a rather important step in life however that can be changed and made flexible any time. Choosing a vocation means choosing a life style.

Vocational preference is described as the process of choosing one vocation among a group of vocations. While making the vocational preference, the individual spends a time in which he/she determines suitable/unsuitable vocations for himself/herself. There are subjective and objective factors in vocational preference. Subjective factors are interest, demand, skill and social status; objective factors are payment, income and promotion, it means social security and economic return (London, Würzburg \& Berne 1972). The three variables that become prominent in the vocational preference of the individual are skill, value and interest. While making a choice, the individual compares his very own details (interest, life style, values, skill etc.) with the options at hand (vocations, sectors, location of companies, social security, etc.) and by means of this matching he/she chooses a vocation (Varçın et al. 2005).

Kuzgun (2000) describes that the preference of a vocation is arraying the vocations in terms of desirability and emphasizes that factors like interest, social reputability and income effect this preference. Gottfredson's theory (1981) is one of 
the more applied theories in the field of vocational goal construction. This theory is presented and discussed in terms of its fundamental concepts: Self - ego, vocational perception, cognivite map of preference, vocational accessibilitiy and compromise process, vocational choice and vocational aspiration (As cited in Külahoğlu, 2001). It is emphasized in International Association for Educational and Occupational Guidance (2002) that in determining the aims of the individual, the values, interests and career decision should always be reviewed.

Strong (1943), who has carried out the very first study about the interest, describes interest as follows: “The 'liking', 'not liking' or 'being indifferent' reaction of a person against another person, thing or action" (As cited in Herr \& Cramer, 1996). Interest, according to Psychological and Psychoanalytic Terms Dictionary (A Comprehensive Dictionary of Psychological and Psychoanalytic Terms), is described as distinguishing an object or situation, or the attitude or sense in form of selforientation (As cited in Savickas, 1999). There are many studies and scales developed about interest too. (Balk1s, 2004; Barak \& Cohen, 2002; Gasser, Larson, \& Borgen, 2007; Helledey, Zytowski, \& Fouada, 2004; Rottinghaus, Coon, Gaffey, \& Zytowski, 2007). One of them is vocational interest.

Vocational interest is regarded as an aspect of interest concept. Holland (1985) describes the vocational interest as a part of personality and indicates that it is the sign of the personality at work, lectures at school, hobbies, leisure time activities and preferences. Many psychometrists have described vocational interests as "I like", "I do not like" or "Does not matter" reactions given by the individual in situations concerning vocations and facilities (Savickas, 1999). Despite different points of view, there are many common points in describing vocational interests. Based on this information, interest may be defined as internal process when upon request of the individual he/she pays attention to an object without extra effort, keeps it for long, is aware of it and converts this into reaction and behavior.

Low and Rounds (2007) indicate that the vocational interests are affected by characteristics like identity formation; cognitive, social and emotional evolution, hormonal, psychological and physical changes so much as it is affected by family, school and peers during the adolescence. Exclusive to Turkey, individuals make their choices according to the point they get from the university entrance exam, that is to say in terms of information and skill rather than interest.

Vocational interests can be determined in two different ways as disclosed and measured ones. The disclosed information are in the form expression of how the individual is directly interested in which job. The measured interests are put through via inventory. Although there are different methods used in measuring vocational interests, the most common method is measuring via interest inventory (Silvia, 2006), Strong Interest Inventory-SII, Kuder Preference Record-Occupational, Kuder Career Search - KCSonline, Holland's (Self-Directed Search-SDS), Kuzgun's Academic SelfConcept Scale (ABKÖ), Kuzgun's Self-Assessment Inventory (KDE), Newspaper News Test (GHT) and Occupational Field Interest Inventory (OFII) are some of the scales used in determining vocational interests. Their usage at the present time on computers helps their proliferation. In terms of gender (Betz \& Schifano, 2000; Eccles, 1993), racial/ethnic group (Leong, 1995) and socio-economic status (SES) (Bandura et 
al., 2001) there are differences in vocational interest types (As cited in Low, Yoon, Roberts, \& Rounds, 2005).

Gender is the most explicit variable in distinguishing interests (Erdil, 2006; Lippa, 1998, 2005; Low et al., 2005; Rounds, 1995; Sayın, 2000; Su, Rounds, \& Armstrong, 2009; Tay, Drasgow, Rounds, \& Williams, 2009). Many studies, literature reviews and meta analyses show that men are interested in vocations concerning objects, whereas women are interested in vocations in which you work with people. In the same manner, their choices are parallel to their interests (Lippa, 1998, 2005; Low et al., 2005; Rounds, 1995; Su et al., 2009; Tay et al., 2009). Low and Rounds (2007) state that interests are in line with gender. According to these studies, women and men tend to be interested in activities and vocations which are stereotyped for their gender. Low et al. (2005) have reached the result that there are differences between women and men for changeability of interests. In their study, they came through that the interests of men are more stable than women's.

On the other hand, Anderson, Tracey and Rounds (1997) compared women and men in the sense of General Occupational Field which is included in Strong's Interest Inventory and observed no significant difference between them. Another study, though, is in contrast with this result. According to Rounds and Day (1999) women and men are put in for various fields in the business life in terms of tradition, social structure and opportunities.

Deng, Armstrong and Rounds (2007) came up with the conclusion that gender has determinative affect on vocational interest structures. These researchers analyzed the gender difference in respect of Holland's six-personality types and together with the results they recommended realistic vocations for men and social ones for women. In view of Holland's theory, people with realistic personality are interested in objectoriented vocations.

The most evident vocation in this dimension is engineering (Choices Interest Profiler and UCF Majors, 2012). Similar to this result, according to Armstrong and Rounds (2008), cited Reardon, Vernick and Reed (2004) as finding the vocations in labor market where women and men are dominant disperse unequally in Holland's six-personality model. In labor market, men tend to be dominant in investigative and realistic ones, whereas women tend to be dominant in social and conventional vocations. As a result of the 35-year longitudinal study carried out by Lubinski and Benbow (2006); although women with high levels of math proficiency prefer mathematics and science fields, they cannot build a career as successful as men in these fields. Nevertheless, they observed that women build career in vocations like health, law and social sciences which require multidimensional (math ability as well) abilities. Among the individuals who were monitored, men and women are equally happy in their preferences in mid-thirties and successful in direction of aim determined by themselves.

SES is another variable in determining vocational interests. Lent (2005) states that the career of the individual is affected both by the role in her/his life and with SES, and according to the information gained from Lent, the career life of the individual is built in the way of her/his past life. Lent states that SES is another important variable in vocational interests together with ethnic origin, genetics and physical health. 
According to Patton and McMahon (2006) cited Holland (1998) as finding, gender and SES are important variables for vocational interest and preference. Bütün (1998) reached the conclusion in his/her study that SES is also effective in determining the interests of female students together with the vocation and educational background of mother and father and birth order. Erdil (2006), on the other hand, came through in his/her study on females and males that the number of the attended university entrance exams, educational level of mother-father, income level and type of the graduated high school are effective on vocational preference. Strong (1943) states that interests are permanent and not affected sufficiently by the vocational education and experience for estimating future behaviors. Yet, McArthur (1954) assumes that this relation seems to be changeable by SES (Betsworth \& Fouad, 1997).

All these studies show that vocational preference and interest are affected by a great deal of variables. One's professional interests should affect their career choices. However, a wealth of research observations made in Turkey indicated that individuals most often choose their occupation based on their idiosyncratic skills, as well as, from influences in their personal environment. In this study, the relations were analyzed between the gender, socio-economic status (SES) variables and the vocational interest and the vocational preference. To indicate vocational interest "OFII" was used. In this investigation, a determination was made regarding participants' vocational choices based on their observed majors of study or their job profession. As a result, in this investigation the concept of professional interest was measured using OFII in 14 dimensions, and the occupational preferences were limited to the participants' university department.

\section{Method}

\section{Research Design}

This study focuses on examining the relations between the variables, therefore, it can be classified as a correlational survey model. Correlational survey model, which states the relations gained by comparison and correlations between variables, is one of the descriptive survey models (Karasar, 2011). In correlational survey model while determining the survey problem and the variables, it is necessary to get support from previous survey results, the theory, expert views or experiences in order to determine whether the relationship is worth examining or not.

\section{Participants}

In total 812 students, who study at preparatory classes, took part in this study. $495(61.0 \%)$ of the students are from Ankara University and $317(39.0 \%)$ of them are from Yıldırım Beyazıt University. Of the participants, 431 (51.1\%) were female, 380 $(46.9 \%)$ were male and one person did not will to state gender. When observed with regards to ages, $702(86.6 \%)$ of the participants were at the age of 19-20, $90(11.1 \%)$ of them were above 20 and 19 (2.3\%) of them were 18 and below. One participant did not will to state age.

Table 1 shows the distribution of the participants in respect of their departments of current higher-education. 
Table 1

The Distribution of The Participants According To Their Departments of Current Higher-Education.

\begin{tabular}{lcc}
\hline Departments & $\boldsymbol{n}$ & $\mathbf{\%}$ \\
Mathematics & 2 & 0.3 \\
Computer & 15 & 2.0 \\
Foreign Language & 14 & 1.8 \\
Visual Arts & 2 & 0.3 \\
Turkish Language (Literature) & 1 & 0.1 \\
Law & 62 & 8.1 \\
Agriculture & 5 & 0.7 \\
Communication & 40 & 5.2 \\
Engineering & 145 & 19.0 \\
Political-Financial Sciences & 243 & 31.8 \\
Physical Sciences & 4 & 0.5 \\
Medicine & 127 & 16.6 \\
Computer Engineering & 52 & 6.8 \\
Physics/Chemistry/Biology & 52 & 6.8 \\
Total & $\mathbf{7 6 4}$ & $\mathbf{1 0 0 . 0}$ \\
Missing & $\mathbf{4 8}$ & \\
\hline
\end{tabular}

When departments of current higher-education of the participants are analyzed, the result is as follows: $243(31,8 \%)$ from political sciences, $145(19,0 \%)$ from engineering and $127(16,6 \%)$ from medicine. It is seen that the least participation comes from mathematics, visual arts, Turkish Language (literature), agriculture and physical sciences.

\section{Research Instrument}

Occupational Field Interest Inventory (Mesleki Alan İlgi Envanteri/MAİ-OFII), developed by Deniz (2009), which aims to determine vocational interest of individuals, was used in this study.

Occupational Field Interest Inventory (OFII). This inventory aims to measure the interest of individuals in 14 vocational fields; these are Mathematics, Computer, Foreign Languages, Visual Arts, Psychology, Education, Turkish Language, Law, Agriculture-Outdoor, Communication-Mass Media, Engineering, Political-Financial Sciences, Science, Health Sciences. After reading the items, the participant marks, with reference to her/his interest, the most suitable choice from "Really attracts my attention (5)" to "Does not really attract my attention (1)". Within the scope of this study, the form of OFII consisting of 156 items, and among these 156 items the OFII short form (OFII-SF) consisting of 72 items that is formed by the items contributing most to the extend they belong, were used. Statics were calculated after raw scores were converted into $\mathrm{z}$ score, since the dimensions of the applied scales were same, but the numbers of items were different. 
The Validity and Reliability of Research Instrument.

In some of the scale development and adaptation studies only confirmatory factor analysis (Kocayörük, 2010) was used in order to determine validity while in some others exploratory and confirmatory factor analyses (Aypay, 2012; Baloğlu, Karadağ, \& Karaman, 2008; Büyüköztürk, Akgün, Özkahveci, \& Demirel, 2004; Doğan \& Çetin, 2009; Eren-Gümüş, 2010; Kapıkıran \& Kapıkıran, 2011; Özyürek, 2010; Talepasand, Alijani, \& Bigdeli, 2010; Yıldı, Akpınar, Tatar, \& Ergin, 2009) were performed.

During the development of OFII, exploratory factor analysis was carried out with regard to constructive validity. As a result of this analysis it was concluded that 14 factors represent $49 \%$ of the total variance. Via confirmatory factor analysis which was carried out later on, it was seen that goodness of fit indexes obtained values between $0.87-0.99$. In addition, for the validity studies of the scale, totally 88 academicians were asked to give their opinion about the reflection of items on the fields to be at least three academicians with PhD level in relevant field for each of 14 different fields. As another proof of the constructive validity, the correlation among 14 dimensions of the scale was calculated. The calculated correlation values were 0.43 to 0.50 and correlation median was $r=0.07$. This result was interpreted that the dimensions were clearly separated from each other.

In some of the scale development and adaptation studies Cronbach alpha coefficients were calculated (Akın, 2008; Aypay, 2011; Baloğlu vd., 2008; Büyüköztürk vd., 2004; Yıldız vd., 2009). With regard to reliability studies of OFII, internal consistency reliability (Cronbach alpha) was ascertained and it was observed that Cronbach alpha value, which is estimated for each dimension, varied between 0.79 (Agriculture-Outdoor) and 0.95 (Law) and the median value of the reliability was 0.89 . As another proof of the reliability, after form OFII consisting of 156 items was created, the test-retest reliability was estimated again and it was seen that the obtained reliability values varied from 0.75 (Agriculture-Outdoor) to 0.95 (Law) values and median value was 0.89 .

Validity and reliability results gained for two forms of scale within the scope of this study are as follows: As a result of the confirmatory factor analysis; the goodness of fit indexes of the sub-dimensions involved in OFII short form were analyzed. Accordingly, it was observed that GFI (0.94-1.00), AGFI (0.82-0.99), CFI (0.89-1.00), NNFI (0.78-1.00) goodness of fit indexes and RMSEA (0-0.17) nonconformity indexes had mostly sufficient values. Besides, it was seen that when one item from each of Mathematics, Visual Arts and Foreign Language sub-dimensions was omitted, which increases the chi-square values; GFI (0.96-1.00), AGFI (0.92-0.99), CFI (0.95-1.00), NNFI (0.91-1.00) goodness of fit indexes increased and RMSEA (0-0.13) nonconformity indexes decreased.

The goodness of fit indexes on OFII form were analyzed either. Accordingly, it was observed that GFI (0.84-0.95), AGFI (0.77-0.93), CFI (0.85- 0.98), NNFI (0.81-0.98) goodness of fit indexes and RMSEA (0.063-0.14) nonconformity index had mostly sufficient values. Besides, it was seen that when one item from each of Mathematics, Psychology, Turkish Language, Communication-Mass Media, Engineering, Visual Arts and Foreign Language dimensions was omitted, which increases the chi-square 
values; GFI (0.89-0.95), AGFI (0.83-0.93), CFI (0.90- 0.98), NNFI (0.87-0.98) goodness of fit indexes increased and RMSEA (0.063-0.12) nonconformity indexes decreased.

With regard to reliability study of the scale, Cronbach alpha reliability coefficients were estimated. Table 2 gives the Cronbach alpha reliability coefficients regarding OFII-SF and OFII which were estimated to the participants.

Table 2

Cronbach alpha Reliability Coefficients Regarding OFII-SF and OFII

\begin{tabular}{lcc}
\hline Sub-dimensions & OFII-SF & OFII \\
\hline Mathematics & 0.76 & 0.88 \\
Computer & 0.86 & 0.93 \\
Foreign Language & 0.70 & 0.82 \\
Visual Arts & 0.74 & 0.81 \\
Psychology & 0.78 & 0.87 \\
Education & 0.74 & 0.79 \\
Turkish Language (Literature) & 0.59 & 0.81 \\
Law & 0.92 & 0.94 \\
Agriculture-outdoor & 0.67 & 0.76 \\
Communication-Mass Media & 0.73 & 0.87 \\
Engineering & 0.89 & 0.90 \\
Political-Financial Sciences & 0.90 & 0.92 \\
Science & 0.78 & 0.87 \\
Health & 0.86 & 0.89 \\
\hline
\end{tabular}

The internal consistency values (Cronbach alpha) of OFII-SF and OFII regarding this study were found. It was observed that the Cronbach alpha value, which was estimated with respect to all dimensions regarding OFII-SF, varied between 0.59 (Turkish Language) and 0.92 (Law). It was observed that the Cronbach alpha value, which was estimated with respect to all dimensions regarding OFII, varied between 0.76 (Agriculture-outdoor) and 0.94 (Law).

\section{Procedure}

OFII and OFII-SF were applied to preparatory classes of Ankara University and Yıldırım Beyazıt University. The application was performed in 2011-2012 academic year's spring term by researchers entering the classes and giving information about the application. Within the personal information part added to the beginning of OFII and OFII-SF, the participants were asked about their departments of current highereducation, the number of books purchased, the frequency of the participation of parents in social activities, educational level of mother and father, vocation of mother and father, monthly income, possession of house and car. The SES of the participants were determined by number of books purchased, the frequency of the participation of parents in social activities, educational and income level of mother and father. Before the application, within the framework the legal rights knowledge of the participants was ensured and the motivation of the participants was improved by stating that the results regarding 14 fields of interest would be submitted. At the end 
of the study, the results and their interpretations were submitted to each student in coordination with directors of both universities.

\section{Data Analysis}

After collecting the research data, the data of the ones, who filled the scale fully and correctly, were saved to computer and arranged. After the reliability and validity values of the scales were determined, the phase of data analysis started.

Before the analyzes, the raw scores obtained via OFII and OFII-SF were converted into $\mathrm{z}$ score. In addition to the determination of descriptive statistics for the analysis of data; chi-square $(\alpha=.05)$, independent samples $t$ test $(\alpha=.05)$ and one way ANOVA statistics $(a=.05)$ were applied.

\section{Results}

After defining descriptive statistics in the research, the findings were respectively transferred with reference to gender and SES. Table 3 shows chi-square values of the departments of current higher-education of the students with regard to gender.

\section{Table 3}

Chi-Square Values of the Departments of Current Higher-Education of the Students with Regard to Gender

\begin{tabular}{|c|c|c|c|c|}
\hline & & Female(N=382 & Male $(\mathrm{N}=371)$ & Total \\
\hline \multirow[t]{2}{*}{ For.Lang. } & $\mathrm{n}$ & 8 & 6 & 14 \\
\hline & $\%$ & 57 & 43 & 100 \\
\hline \multirow[t]{2}{*}{ Law } & $\mathrm{n}$ & 48 & 14 & 62 \\
\hline & $\%$ & 77 & 23 & 100 \\
\hline \multirow[t]{2}{*}{ Commun } & $\mathrm{n}$ & 21 & 19 & 40 \\
\hline & $\%$ & 52 & 48 & 100 \\
\hline \multirow[t]{2}{*}{ Engine } & $\mathrm{n}$ & 50 & 95 & 145 \\
\hline & $\%$ & 34 & 66 & 100 \\
\hline \multirow[t]{2}{*}{ Political } & $\mathrm{n}$ & 113 & 129 & 242 \\
\hline & $\%$ & 47 & 53 & 100 \\
\hline \multirow[t]{2}{*}{ Medicine } & $\mathrm{n}$ & 77 & 50 & 127 \\
\hline & $\%$ & 61 & 39 & 100 \\
\hline \multirow[t]{2}{*}{ Comp.Eng. } & $\mathrm{n}$ & 32 & 35 & 67 \\
\hline & $\%$ & 48 & 52 & 100 \\
\hline \multirow{2}{*}{$\begin{array}{c}\text { Physics } \\
\text { Biology (P.C.B) }\end{array}$} & $\mathrm{n}$ & 33 & 23 & 56 \\
\hline & $\%$ & 59 & 41 & 100 \\
\hline
\end{tabular}

$X^{2}(7)=41.56 ; \mathrm{p}<.001$

It was observed that there is significant difference with respect to gender among the departments of current higher-education of the students $\left(X^{2}(7)=41.56 ; p<.001\right)$. It can be observed that these differences are in favor of women especially in law and medicine, and in favor of men in engineering. 
In the research, it was examined whether sub-dimensions of OFII showed significant difference regarding gender or not. After the $\mathrm{z}$ scores of the individuals were calculated, $t$ test analysis of the OFII sub-dimensions with respect to gender was carried out. Table 4 shows these findings.

\section{Table 4}

The Results of Independent Samples $t$ Test-to OFII Sub-Dimensions-according to Gender

\begin{tabular}{|c|c|c|c|c|c|c|c|}
\hline & Gender & $\mathrm{N}$ & $\overline{\boldsymbol{X}}$ & Sx & $\mathrm{df}$ & $\mathrm{t}$ & $\mathrm{p}$ \\
\hline \multirow[t]{2}{*}{ Mathematics } & Female & 431 & -0.30 & 1.00 & 809 & 1.66 & .096 \\
\hline & Male & 380 & -0.17 & 1.03 & & & \\
\hline \multirow[t]{2}{*}{ Computer } & Female & 431 & -0.60 & 0.81 & 699.87 & 8.51 & $.000^{* * *}$ \\
\hline & Male & 380 & -0.02 & 1.07 & & & \\
\hline \multirow[t]{2}{*}{ Foreign Language } & Female & 431 & -0.22 & 1.10 & 809 & 2.29 & $.022^{*}$ \\
\hline & Male & 380 & -0.39 & 1.02 & & & \\
\hline \multirow[t]{2}{*}{ Visual Arts } & Female & 431 & -0.16 & 1.15 & 802.65 & 2.15 & $.031^{*}$ \\
\hline & Male & 380 & -0.32 & 0.92 & & & \\
\hline \multirow[t]{2}{*}{ Psychology } & Female & 431 & 0.07 & 1.09 & 804.25 & 7.80 & $.000^{* * *}$ \\
\hline & Male & 380 & -0.47 & 0.89 & & & \\
\hline \multirow[t]{2}{*}{ Education } & Female & 431 & -0.29 & 1.07 & 809 & 1.31 & .190 \\
\hline & Male & 380 & -0.39 & 1.00 & & & \\
\hline \multirow{2}{*}{$\begin{array}{l}\text { Turkish Language } \\
\text { (Literature) }\end{array}$} & Female & 431 & -0.40 & 1.03 & 809 & 1.34 & .178 \\
\hline & Male & 380 & -0.50 & 0.96 & & & \\
\hline \multirow[t]{2}{*}{ Law } & Female & 431 & -0.24 & 1.09 & 808.88 & 3.16 & $.002^{* *}$ \\
\hline & Male & 380 & -0.47 & 0.97 & & & \\
\hline \multirow[t]{2}{*}{ Agriculture-outdoor } & Female & 431 & -0.52 & 0.83 & 775.07 & 2.35 & $.019^{*}$ \\
\hline & Male & 380 & -0.37 & 0.91 & & & \\
\hline \multirow{2}{*}{$\begin{array}{l}\text { Communication- } \\
\text { Mass Media }\end{array}$} & Female & 431 & -0.21 & 1.09 & 809 & 0.56 & .573 \\
\hline & Male & 380 & -0.25 & 0.98 & & & \\
\hline \multirow[t]{2}{*}{ Engineering } & Female & 431 & -0.53 & 1.01 & 772.80 & 3.28 & $.001^{* *}$ \\
\hline & Male & 380 & -0.28 & 1.10 & & & \\
\hline \multirow{2}{*}{$\begin{array}{l}\text { Political-Financial } \\
\text { Sciences }\end{array}$} & Female & 431 & -0.35 & 0.96 & 761.39 & 4.14 & $.000^{* * *}$ \\
\hline & Male & 380 & -0.04 & 1.09 & & & \\
\hline \multirow[t]{2}{*}{ Science } & Female & 431 & -0.35 & 1.03 & 809 & 2.35 & $.019 *$ \\
\hline & Male & 380 & -0.18 & 1.05 & & & \\
\hline \multirow[t]{2}{*}{ Health } & Female & 431 & -0.10 & 1.04 & 808.99 & 4.40 & $.000^{* * *}$ \\
\hline & Male & 380 & -0.41 & 0.92 & & & \\
\hline
\end{tabular}

$\left({ }^{*} \mathrm{p}<.05,{ }^{* *} \mathrm{p}<.01,{ }^{* * *} \mathrm{p}<.001\right)$

It is observed that there are significant differences between gender and the fields of interest of the students. When Table 4 is analyzed, it is observed that in respect to the field of interests of the individuals, there is a significant difference that Psychology, Health $(p<.001)$, Law $(p<.01)$, Foreign Languages and Visual Arts 
$(p<.05)$ are in favor of female; on the other hand Computer, Political-Financial Sciences $(p<.001)$, Engineering $(p<.01)$, Agriculture-Outdoor and Science $(p<.05)$ are in favor of male.

In this study, it was examined whether the choice of departments of current higher-education showed difference with regard to SES or not. Table 5 shows the chisquare values of the departments of current higher-education the students with regard to SES.

\section{Table 5}

The chi-square Results of the departments of current higher-education of the students with regard to SES

\begin{tabular}{|c|c|c|c|c|c|c|c|c|c|c|c|c|c|c|}
\hline \multirow[t]{2}{*}{$N=538$} & \multicolumn{2}{|c|}{ Law } & \multicolumn{2}{|c|}{ Cотmun } & \multicolumn{2}{|c|}{ Engine. } & \multicolumn{2}{|c|}{$\begin{array}{l}\text { Pol. and } \\
\text { Fin. Sci. }\end{array}$} & \multicolumn{2}{|c|}{ Medicine } & \multicolumn{2}{|c|}{$\begin{array}{l}\text { Comp } \\
\text { Eng. }\end{array}$} & \multicolumn{2}{|c|}{ P.C.B. } \\
\hline & $n$ & $\%$ & $n$ & $\%$ & $n$ & $\%$ & $n$ & $\%$ & $n$ & $\%$ & $n$ & $\%$ & $n$ & $\%$ \\
\hline Higher & 13 & 25 & 10 & 34 & 23 & 17 & 48 & 26 & 29 & 31 & & & & \\
\hline & & & & & & & & & & & & 8 & 2 & 2 \\
\hline Med. & 17 & 33 & 10 & 34 & 44 & 46 & 63 & 35 & 30 & 32 & 18 & 36 & 18 & 49 \\
\hline Low & 22 & 42 & 9 & 32 & 28 & 37 & 71 & 39 & 34 & 37 & 23 & 46 & 7 & 19 \\
\hline Total & 52 & 100 & 29 & 100 & 95 & 100 & 182 & 100 & 93 & 100 & 50 & 100 & 37 & 100 \\
\hline
\end{tabular}

In Table 5, there are some differences at percentages. But these are not conspicuous. When the departments of current higher-education with regard to SES is analyzed, it is observed that there is no significant difference $(\chi 2(12)=14.97 ; p>.05)$. It was determined that some cells' Chi-square value for the expected frequency of less than 5 was higher than $20 \%$. As a result, the items with the lower values were excluded from further analysis.

One-way ANOVA was performed in order to determine whether SES variables (low, medium, high) would create a significant difference on the professional interest variable. 
102 Kaan Zülfikar Deniz, Ersin Türe, Aslı Uysal, E Tuba Akar

Table 6

The ANOVA Results of OFII Sub-dimensions according to SES

\begin{tabular}{|c|c|c|c|c|c|c|}
\hline & & $\begin{array}{l}\text { Sum of } \\
\text { Squares }\end{array}$ & $d f$ & $\begin{array}{l}\text { Mean } \\
\text { Square }\end{array}$ & $F$ & $p$ \\
\hline \multirow[t]{3}{*}{ Mathematics } & Between Groups & 7.57 & 2 & 3.79 & 3.67 & 0.03 \\
\hline & Within Groups & 609.54 & 591 & 1.03 & & \\
\hline & Total & 617.11 & 593 & & & \\
\hline \multirow[t]{3}{*}{ Computer } & Between Groups & 0.65 & 2 & 0.33 & 0.33 & 0.72 \\
\hline & Within Groups & 588.00 & 591 & 1.00 & & \\
\hline & Total & 588.65 & 593 & & & \\
\hline \multirow{3}{*}{$\begin{array}{l}\text { Foreign } \\
\text { Language }\end{array}$} & Between Groups & 0.58 & 2 & 0.29 & 0.25 & 0.78 \\
\hline & Within Groups & 695.58 & 591 & 1.18 & & \\
\hline & Total & 696.16 & 593 & & & \\
\hline \multirow[t]{3}{*}{ Visual Arts } & Between Groups & 4.79 & 2 & 2.40 & 2.14 & 0.12 \\
\hline & Within Groups & 662.17 & 591 & 1.12 & & \\
\hline & Total & 666.96 & 593 & & & \\
\hline \multirow[t]{3}{*}{ Psychology } & Between Groups & 0.30 & 2 & 0.15 & 0.13 & 0.88 \\
\hline & Within Groups & 662.83 & 591 & 1.12 & & \\
\hline & Total & 663.13 & 593 & & & \\
\hline \multirow[t]{3}{*}{ Education } & Between Groups & 3.74 & 2 & 1.87 & 1.59 & 0.21 \\
\hline & Within Groups & 696.02 & 591 & 1.18 & & \\
\hline & Total & 699.76 & 593 & & & \\
\hline \multirow{3}{*}{$\begin{array}{l}\text { Turkish } \\
\text { Language } \\
\text { (Literature) }\end{array}$} & Between Groups & 1.76 & 2 & 0.88 & 0.83 & 0.44 \\
\hline & Within Groups & 627.29 & 591 & 1.06 & & \\
\hline & Total & 629.04 & 593 & & & \\
\hline \multirow[t]{3}{*}{ Law } & Between Groups & 2.59 & 2 & 1.30 & 1.19 & 0.30 \\
\hline & Within Groups & 641.89 & 591 & 1.09 & & \\
\hline & Total & 644.48 & 593 & & & \\
\hline \multirow{3}{*}{$\begin{array}{l}\text { Agriculture- } \\
\text { outdoor }\end{array}$} & Between Groups & 1.31 & 2 & 0.65 & 0.88 & 0.42 \\
\hline & Within Groups & 439.77 & 591 & 0.74 & & \\
\hline & Total & 441.08 & 593 & & & \\
\hline \multirow{3}{*}{$\begin{array}{l}\text { Communication } \\
\text {-Mass Media }\end{array}$} & Between Groups & 2.51 & 2 & 1.26 & 1.08 & 0.34 \\
\hline & Within Groups & 689.69 & 591 & 1.17 & & \\
\hline & Total & 692.21 & 593 & & & \\
\hline
\end{tabular}


Table Continued....

\begin{tabular}{llrrrrr}
\hline Engineering & Between Groups & 4.13 & 2 & 2.07 & 1.87 & 0.16 \\
& Within Groups & 652.59 & 591 & 1.10 & & \\
& Total & 656.72 & 593 & & & \\
Political- & Between Groups & 0.69 & 2 & 0.35 & 0.32 & 0.73 \\
Financial & Within Groups & 650.36 & 591 & 1.10 & & \\
Sciences & Total & 651.05 & 593 & & & \\
Science & Between Groups & 3.24 & 2 & 1.62 & 1.49 & 0.23 \\
& Within Groups & 641.76 & 591 & 1.09 & & \\
& Total & 645.00 & 593 & & & \\
Health & Between Groups & 1.42 & 2 & 0.71 & 0.75 & 0.48 \\
& Within Groups & 561.87 & 591 & 0.95 & & \\
& Total & 563.291 & 593 & & & \\
\hline
\end{tabular}

It was observed that there is no significant different for all sub-dimensions of OFII excluding Mathematics between SES and the field in which students are interested according to OFII $(F(2,591)=3.67 ; \mathrm{p}<.05)$. As for Mathematics field, a significant difference in favor of common group between higher and medium SES was observed $(\mathrm{p}<.05)$.

\section{Discussiona and Conclusions}

In this study, the relation of the gender and SES with vocational interest was analyzed. To indicate vocational interest "OFII" was used. When the findings are examined, it is observed that the number of the ones preferring the departments at universities is in favor of women for law and medicine; in favor of men in engineering. In addition to this finding, it was found significant that the point differences with regard to OFII sub-dimensions are in favor of women for Psychology, Health, Law, Foreign Languages and Visual Art; in favor of men for Computer, Political and Financial Sciences, Engineering, Agriculture-outdoor and Physical Science. It can be asserted that these findings are in conformity with the gender-vocational interest studies. Many studies show that the interest of the women for social vocations, which require working with people, is higher, while interest of men for the vocations which require working with objects and abstract concepts is higher (Lippa, 1998, 2005; Low et al., 2005; Rounds, 1995; Su et al.,2009; Tay et al., 2009; Y1lmaz, 2006). In addition, according to Low and Rounds (2007) women and men tend to be interested in activities and vocations which are stereotyped for their gender.

When above mentioned details are analyzed in detail, it is observed that the interest of the women is higher for the vocations which needs working with people (Psychology, Health, Law), and interest of men is higher for the vocation which need working with objects (Engineering, Agriculture-Outdoor, Science, Computer). 
Although foreign language department is not regarded as a social vocation, the individuals graduating from this department tend to be a teacher. It corroborates the emphasis of the Low and Round (2006) about stereotyped vocations and activities for genders that women are more interested in Visual Arts. Although the political way of the Political and Financial Sciences, which is in favor of men, requires working with people, politics is an vocation imputed to men by society. The fact that there is no significant difference observed at some fields may match up with the study by Anderson et al. (1997) which indicates that there is no significant difference regarding vocational interest between women and men. Besides, certain fields such as communication and media are preferred by both men and women. This result was consistent with Çınar's (2013) finding in which the variable of gender exhibited no effect on the career and/or occupational preferences of college students and graduates.

The obtained findings regarding gender correspond to studies on personality types in Holland's theory. For instance, Deng et al. (2007) recommended realistic vocations for men and social vocations for women. In view of Holland's theory, people with realistic personality are interested in object-oriented vocations. The best examples in this manner would be vocations like engineering (Choices Interest Profiler and UCF Majors, 2012). According to Armstrong and Rounds (2008), in labor market, men tend to be dominant in investigative and realistic vocations, whereas women tend to be dominant in social and conventional vocations. All these studies explain the significant differences arising with regard to gender.

There was no significant difference observed regarding vocational interest, when the study findings were analyzed with respect to SES. In contrast, a significant difference in favor medium SES was found in mathematics interest. When the literature was reviewed, it was observed that SES is an important variable affecting vocational interest, however within the studies analyzed there was no information about which SES makes difference in which field (Betsworth \& Fouad, 1997; Lent, 2005; Patton \& McMahon, 2006). Within this study the number of books purchased, the frequency of the participation of parents in social activities, educational and income level of mother and father were used in determining SES. SES is a very relative concept featuring many variables. For the studies which will be made in the future, some other variables can also be preferred to determine SES. In addition, this study was performed in Ankara University and Yıldırım Beyazıt University. Since these are state universities, we may not have reached the high SES (especially for income variable). Private universities can also be included in future studies.

The results of the study show that gender is an important variable for vocational interest. Consultants who provide vocational guidance services should consider gender variable for vocational interests. It should be remembered that women can be happier with the vocations requiring to work with people and men can be happier with the vocation requiring to work with objects. 


\section{References}

Akın, A. (2008). Psikolojik iyi olma ölçekleri: Geçerlik ve güvenirlik çalışması [The Scales of Psychological Well-being: A Study of Validity and Reliability]. Kuram ve Uygulamada Ĕ̆itim Bilimleri Dergisi, 8 (3), 721-750.

Anderson, M. Z., Tracey, T. J. G., \& Rounds, J. (1997). Examining the invariance of Holland's vocational interest model across gender. Journal of Vocational Behavior, 50, 349 -364.

Armstrong, P. I., \& Rounds, J., (2008). Vocational psychology and individual differences. In S. Brown \& R. Lent (Eds.), Handbook of Counseling Psychology (4th ed., pp. 375-391). New York: Wiley.

Aypay, A. (2011). İlköğretim II. Kademe Öğrencileri İçin Okul Tükenmişliği Ölçeği: Geçerlik ve güvenirlik çalışması [Elementary School Student Burnout Scale for Grades 6-8: A Study of Validity and Reliability]. Kuram ve Uygulamada Eğitim Bilimleri Dergisi, 11 (1), 511-527.

Aypay, A. (2012). Ortaöğretim Öğrencileri İçin Okul Tükenmişliği Ölçeği (OOTÖ) [Secondary School Burnout Scale (SSBS)]. Kuram ve Uygulamada Eğitim Bilimleri Dergisi, 12 (2).

Balkıs, M. (2004). Kendini Araştırma Ölçeği'nin (KAÖ) Türk kültürüne uyarlanması [An adaptation study of the self-directed search in Turkish culture]. Eğitim Araştırmaları Dergisi, 17, 54-63.

Baloğlu, N., Karadă̆, E., \& Karaman, H. (2008). Stratejik Planlama Tutum Ölçeği: Açımlayıcı ve doğrulayıcı faktör analizi çalışması [The Strategic Planning Attitude Scale: A Study of Exploratory and Confirmatory Factor Analyses]. Kuram ve Uygulamada Ĕ̆itim Bilimleri Dergisi, 8 (2).

Barak, A., \& Cohen, L. (2002). Empirical examination of an online version of the selfdirected search. Journal of Career Assessment, 10 (4), 387-400.

Betsworth, D. G., \& Fouad, N. A. (1997). Vocational interests: A look at the past 70 years and a glance at the future. The Career Development Quarterly. Volume 46, Issue 1, pages 23-47. DOI: 10.1002/j.2161-0045.1997.tb00689.x Article first published online: 23 Dec 2011.

Bütün, A. (1998). Farklı sosyo-ekonomik düzeylerdeki genel liselere ve klz meslek liselerine devam eden kız ögrrencilerin mesleki ilgilerinin incelenmesi [A Study on the vocational interest of the girls attending general and vocational high schools from various]. Unpublished doctoral dissertation. Ankara Üniversitesi, Fen Bilimleri Enstitüsü, Ankara.

Büyüköztürk, Ş., Akgün, Ö., Kahveci, Ö., \& Demirel, F. (2004). Güdülenme ve Öğrenme Stratejileri Ölçeği'nin Türkçe formunun geçerlik ve güvenirlik çalışması [The Validity and Reliability Study of the Turkish Version of the Motivated Strategies for Learning Questionnaire]. Kuram ve Uygulamada Ĕ̈itim Bilimleri Dergisi, 4 (2), 207-239. 
Choices Interest Profiler and UCF Majors (2012). University of Central Florida Career Services, Retrieved from

http://www.career.ucf.edu/categories/Students/Undergraduate_Students/ Explore_Majors_and_Careers/Choices_Interest_Profiler_and_UCF_Majors/9 0_47.aspx at 22.05.2012.

Çınar, Y. (2013). Kariyer tercihi probleminin yapısal bir modeli ve riske karşı tutumlar: Olasılıklı DEMATEL Yöntemi temelli bütünleşik bir yaklaşım [A Structural model of career preference problem and attitudes towards risk: A hybrid approach based on stochastic DEMATEL method]. Sosyoekonomi. 19 (1), 157-185.

Deng, C-P., Armstrong, P. I., \& Rounds, J. (2007). The fit of Holland's RIASEC model to US occupations. Journal of Vocational Behavior, 71, 1-21.

Deniz, K. Z. (2009). Occuppational Field Interest Inventory (OFII) development study. Y.Y. Üniversitesi, Eğitim Fakültesi Dergisi. Cilt:VI, Sayı:I, 289-310 http://efdergi.yyu.edu.tr

Doğan, T., \& Çetin, B. (2009). Tromso Sosyal Zeka Ölçeği Türkçe formunun faktör yapısı: Geçerlik ve güvenirlik çalışması [The Validity, Reliability and Factorial Structure of the Turkish Version of the Tromso Social Intelligence Scale]. Kuram ve Uygulamada Ĕ̆itim Bilimleri Dergisi, 9 (2), 691-720.

Erdil, Z. (2006). Hacettepe üniversitesi hazırlık sinıfi öğrencilerinin mesleki ilgi ve yetenek alanlar ile meslek tercihlerini etkileyen bazı faktörleri belirlenmesi [Identification of some factors influencing the career choices and career interests and capabilities of Hacettepe University preparatory students]. Unpublished master's thesis. Hacettepe Üniversitesi Sağllk Bilimleri Enstitüsü, Çocuk Gelişimi ve Eğitimi Programı, Ankara.

Eren-Gümüş, A. (2010). The construct validity, reliability of Self Perception Profile for Adolescents: Original versus revised version. Eurasian Journal of Educational Research 39, 127-144.

Gasser, C. E., Larson, L. M., \& Borgen, F. H. (2007). Concurrent validity of the 2005 Strong Interest Inventory: An examination of gender and major field of study. Journal of Career Assessment, 15 (1), 23-43.

Helledey, K. I., Zytowski, D. G., \& Fouada, N. A. (2004). Kuder Career Search: Testretest reliability and consequential validity. Journal of Career Assessment, 12 (3), 285-297.

Herr, E.L., \& Cramer, S. H. (1996). Career guidance and counseling through the lifespan (Fifth Edition). New York: Longman Inc.

Holland, J. L. (1985). Making vocational choices: A theory of vocational personalities and work environments. (2. Edition). USA: Prentice Hall.

International Association for Educational and Vocational Guidance. (2002). Declaration of educational and vocational guidance. International Journal for Educational and Vocational Guidance, 2, 79-83. 
Kapıkıran-Acun, N., \& Kapıkıran, Ş. (2011). School climate inventory: Exploratory and confirmatory factor analysis and reliability-validity. Eurasian Journal of Educational Research, 42, 117-134.

Karasar, N. (2011). Bilimsel araştırma yöntemi [Scientific research methodology]. Ankara: Nobel

Kocayörük, E. (2010). A Turkish adaptation of the inventory of parent and peer attachment: The reliability and validity study. Eurasian Journal of Educational Research, 40, 131-153.

Kuzgun, Y. (2000). Meslek danışmanlığı [Career counseling]. Ankara: Nobel

Külahoğlu, Ş. (2001). Meslek gelişimine bütünsel bir bakış: Gottfredson'un kurami [An integral view in vocational development: Gottfreedson's theory]. Kuram ve Uygulamada Ĕgitim Bilimleri Dergisi, 12, 1,

Lent, R. W. (2005). A social cognitive view of career development and counseling. In S.D. Brown \& R.W. Lent (Eds.), Career development and counseling: Putting theory and research to work. (pp. 101-130). New York: Wiley.

Lippa, R. A. (1998). Gender-related individual differences and the structure of vocational interests: The importance of the people-things dimension. Journal of Personality and Social Psychology, 74, 996-1009.

Lippa, R. A. (2005). Subdomains of gender-related vocational interests: Do they form a cohesive bipolar M-F dimension? Journal of Personality, 73, 693-729.

London, H. J. E., Würzburg, W. A., \& Berne, R. M. (Eds.), (1972). Encyclopedia of psychology. New York, USA: The Seabury.

Low, K. S. D., Yoon, M., Roberts, B. W., \& Rounds, J. (2005). The stability of vocational interests from early adolescence to middle adulthood: A quantitative review of longitudinal studies. Psychological Bulletin, 131, 713-737.

Low, K. S. D. \& Rounds, J. (2006). Vocational interests: Bridging person and environment. In D. L. Segal \& J. Thomas (Eds.), Comprehensive handbook of personality and psychopathology, Volume I: Personality and everyday functioning (pp. 251-267). NY: Wiley.

Low, K. S. D., \& Rounds, J. (2007). Interest change and continuity from early adolescence to middle adulthood. International Journal of Educational and Vocational Guidance, 7, 23-36.

Lubinski, D. \& Benbow, C. P. (2006). Study of mathematically precocious youth after 35 years: uncovering antecedents for the development of math-science expertise. Perspectives on Psychological Science, 1, 316-345.

Özyürek, R. (2010). Matematik Yetkinlik Beklentisi Bilgilendirici Kaynaklar Ölçeği'nin geçerlik ve güvenirlik çalışmaları [The Reliability and Validity of the Mathematics Self-Efficacy Informative Sources Scale]. Kuram ve Uygulamada Eğitim Bilimleri Dergisi, 10 (1).

Patton, W., \& McMahon, M. (2006). Career development and systems theory: Connecting theory and practice (2nd ed.). Rotterdam, The Netherlands: Sense. 
Rottinghaus, P. J., Coon, K. L., Gaffey, A. R., \& Zytowski, D. G. (2007). Thirty-year stability and predictive validity of vocational interests. Journal of Career Assessment, 15 (1), 5-22.

Rounds, J. B. (1995). Vocational interests: Evaluation of structural hypotheses. In D. Lubinski \& R. V. Dawis (Eds.), Assessing individual differences in human behavior: New concepts, methods, and findings (pp. 177-232). Palo Alto, CA: Consulting Psychologists Press.

Rounds, J., \& Day, S. X. (1999). Describing, evaluating, and creating vocational interest structures. In M. L. Savickas \& A. R. Spokane (Eds.), Vocational interests: Their meaning, measurement and use in counseling (pp. 103-133). Palo Alto, CA: Davies-Black.

Savickas, M. L. (1999). The psychology of interests. In M. L. Savickas \& A. R. Spokane (Eds.), Vocational interests: Meaning, measurement and counseling use. USA: Davies-Black.

Sayın, S. (2000). Lise öğrencilerinin mesleki ilgilerini yordayan bazı değişkenler [Some variables predicting high school students vocational interest]. Unpublished doctoral dissertation. Hacettepe Üniversitesi, Sosyal Bilimler Enstitüsü, Ankara.

Silvia, P. J. (2006). Exploring the psychology of interest. New York: Oxford University Press.

Strong, E. K. (1943). Vocational interests of men and women. Stanford, California: Stanford University.

Su, R., Rounds, J., \& Armstrong, P. I. (2009). Men and things, women and people: A meta-analysis of sex differences in interests. Psychological Bulletin, 135, 859884.

Talepasand, S., Alijani, F., \& Bigdeli, I. (2010). Validation of the Social Achievement Goal Orientation Scale in Iranian students. Eurasian Journal of Educational Research, 40, 17-31.

Tay, L., Drasgow, F., Rounds, J., \& Williams, B. A. (2009). Fitting measurement models to vocational interest data: Are dominance models ideal? Journal of Applied Psychology, 94, 1287-1304.

Varçın, R., Ergün, G., Gülçubuk, B., Öğülmüş, S., Özgenç, Ö.Y., Pişkin, M., Savc1, İ., \& Deniz, K. Z. (2005). İşletmelerde kariyer planlaması el kitabı , [The handbook of career planning in Business]. (Ed. R. Varçın). Ankara: Odak.

Yıldız, E., Akpınar, E., Tatar, N., \& Ergin, Ö. (2009). İlköğretim öğrencileri için geliştirilen Biliş Üstü Ölçeği'nin açımlayıcı ve doğrulayıcı faktör analizi [Exploratory and Confirmatory Factor Analysis of the Metacognition Scale for Primary School Students]. Kuram ve Uygulamada Eğitim Bilimleri Dergisi , 9 (3), 1573-1609.

Yılmaz, S. (2006). Fen Bilgisi öğretmen adaylarının mekanik konularına karşı tutumlarınin incelenmesi[Analysis of Preservice Science Teachers' Attitudes toward Mechanics' Concepts]. Eğitim Araştırmaları Dergisi, 24, 199-208. 


\section{Cinsiyet ve Sosyo-ekonomik Düzey Açısından İncelenmesi}

\section{Özet}

Atıf:

Deniz, K. Z., Türe, E., Uysal, A., \& Akar, T. (2014).Investigation of vocational interest and vocational preference in terms of gender and socio-economic status. Eurasian Journal of Educational Research, 57, 91-112 http://dx.doi.org/10.14689/ejer.2014.57.1

\section{Problem Durumu}

Bireyler yaşamlarını sürdürme, beslenme, barınma, güvencede olma, toplumda iyi bir konumda olma vb. amaçları gerçekleştirmek için bir mesleği tercih etme eğilimindedir. Genellikle ergenlik dönemi görevlerinden birisi olan meslek seçimi kimine göre yaşamın en önemli adımı, kimine göre ise yaşamda çok önemli ama her an değiştirilebilir ve esnetilebilir bir adımdır. Meslek seçmek bazen yaşam biçimini seçmektir. Mesleki tercih, bir grup meslekten birini seçme süreci olarak tanımlanmaktadır. Birey mesleki tercih yaparken genellikle kendisi için uygun olan ve olmayanları belirlemeye yönelik bir süreç geçirir. Bireyin hedeflerinin belirlenmesinde, değerlerinin, ilgilerinin ve kariyer kararlarının sürekli gözden geçirilmesi gerektiği vurgulanmaktadır.

Cinsiyet ilgileri ayırmada önemli bir değişken olarak karşımıza çıkmaktadır. Yapılan pek çok araştırma, literatür taraması ve meta analizi çalışması erkeklerin nesnelerle kadınlarınsa insanlarla birlikte çalışmaya ilişkin mesleklerle ilgilendiklerini göstermektedir. Aynı zamanda tercihleri de ilgilerine paralel olarak bu şekilde ortaya çıkmaktadır. Mesleki ilgilerin belirlenmesinde bir başka değişken sosyo-ekonomik düzey (SED)'dir. Yapılan araştırmalar meslek seçimi ve mesleki ilginin cinsiyet, etnik köken, genetik, fiziksel sağlıkla birlikte SED gibi pek çok değişkenden etkilendiğini göstermektedir. Bireylerin mesleki ilgileri ve mesleki tercihleri etkileyen faktörleri ortaya koymak mesleki yönlendirmede kararlarında daha isabetli olmasını sağlayacaktır.

\section{Araştırmanın Amacı}

$\mathrm{Bu}$ araştırmanın amacı Mesleki Alan İlgi Envanteri (MAİ) yardımıla mesleki ilgileri ve mesleki tercihleri etkileyen faktörleri ortaya koymaktır.

\section{Araştırmanın Yöntemi}

Araştırmaya 2011-2012 eğitim-öğretim yılı bahar döneminde Ankara Üniversitesi'nin ( $N=495)$ ve Yıldırım Beyazıt Üniversitesi'nin ( $N=317)$ hazırlık sınıflarında öğrenim gören 812 öğrenci katılmıştır. Bunlardan 243'ü siyasal bilimler, 145'i mühendislik 127'si tıp bölümlerinde öğrenim görmektedir. En az katılımcı sayısının ise matematik, görsel sanatlar, dil (edebiyat), ziraat ve fen bilimleri bölümlerindendir.

Araştırmada bireylerin mesleki ilgilerini tespit etmeyi amaçlayan Mesleki Alan İlgi Envanteri'nin uzun (MAI) ve kısa formu (MAİ-KF) kullanılmıştır. Araştırmada bireylerin mesleki ilgilerini tespit etmeyi amaçlayan MAÍ'nin 156 maddelik formu ve 
bu 156 madde içinden ait olduğu boyuta en çok katkıyı yapan maddelerden oluşturulan 72 maddelik MAİ kısa formu (MAİ-KF) kullanılmıştır.

MAÍnin geliştirme çalışmasında yapı geçerliğine yönelik olarak önce açımlayıcı faktör analizi yapılmıştır. Bu analiz sonucunda 14 faktörün toplam varyansın \%49'unu açıkladığ1 sonucuna ulaşılmıştır. Daha sonra yapılan doğrulayıcı faktör analizi sonucunda uyum indekslerinin 0,87 ile 0,99 arasında değer aldığ görülmüştür. Bunun yanı sıra ölçeğin geçerlik çalışmalarına yönelik olarak 14 farklı alanın her birinden alanında en az doktora derecesine sahip en az üç akademisyen olmak üzere toplamda 88 akademisyenden maddelerin alanlarını yansıtması hakkında görüş alınmıştır. Yapı geçerliğinin bir başka kanıtı olarak ölçeğin 14 boyutunun kendi aralarındaki korelasyonları hesaplanmıştır. Hesaplanan korelasyon değerleri -0,43 ile 0,50 arasında değer almıştır ve korelasyonların medyanı $r=0,07^{\prime}$ dır.

MAÍ'nin güvenirlik çalışmalarına yönelik olarak iç tutarlılık güvenirliği (Cronbach alfa) tespit edilmiştir ve her boyut için hesaplanan Cronbach alfa değerinin 0,79 (Ziraat) ile 0,95 (Hukuk) arasında değiştiği, güvenirliklerin medyan değerinin ise 0,89 olduğu gözlenmiştir. Güvenirlik için bir başka kanıt olarak MAİ 156 maddelik form oluşturulduktan sonra test tekrar test güvenirlik değeri hesaplanmış ve elde edilen güvenirlik değerlerinin 0,75 (Ziraat) ile 0,95 (Hukuk) arasında değiştiği medyan değerinin ise 0,89 olduğu görülmüştür.

Analizler yapılmadan önce MAİ ve MAİ-KF'den elde edilen ham puanlar z puanına dönüştürülmüştür. Verilerin analizinde betimsel istatistiklerin tespit edilmesine ek olarak, ki-kare, t testi ve tek yönlü ANOVA istatistiksel teknikleri kullanılmıştır.

Araştırmanın Bulguları

Araştırma sonucunda bireylerin okudukları bölümler ve ilgi alanları açısından cinsiyete göre anlamlı bir farklılık olduğu gözlenmiştir. Bireylerin öğrenim gördükleri bölümler arasındaki farklılıkların özellikle hukuk ve tıp alanlarında kadınlar lehine, mühendislik alanında erkekler lehine olduğu; ilgi alanları bakımından Psikoloji, Sağlık, Hukuk, Yabancı Dil ve Görsel Sanatlar alanlarında kadınlar lehine; Bilgisayar, Siyasal-Mali Bilimler, Mühendislik, Ziraat ve Fen Bilimleri alanlarında ise erkekler lehinedir.

SED'e göre elde edilen bulgularda ise, bireylerin bölüm tercihleri ve ilgi duydukları alanlar (matematik hariç) açısından anlamlı bir farklılık olmadığı sonucuna ulaşılmıştır. Matematik alanında ise üst ile orta SED arasında orta grup lehine anlamlı fark gözlenmiştir.

Araştırmanın Sonuçları ve Önerileri

Araştırma bulgularının literatürdeki cinsiyet-mesleki ilgi/tercih çalışmalarıyla uyumlu olduğu söylenebilir. Yapılan pek çok araştırma, insanlarla çalışma gerektiren sosyal ağırlıklı mesleklerde kadınların; nesne ve soyut kavramlarla çalışma gerektiren mesleklerde ise erkeklerin ilgisinin/tercihinin daha yüksek olduğunu göstermektedir. Kadınlar ve erkekler kendi cinsiyeti için kalıplaşmış etkinlikler ve mesleklere ilgi duyma eğilimindedirler.

Kadınların ağırlıklı olarak insanlarla (Psikoloji, Sağlık, Hukuk), erkeklerin ise ağırlıklı olarak nesnelerle (Mühendislik, Ziraat, Fen Bilimleri, Bilgisayar) çalışılan mesleklere ilgilerinin yüksek olduğu gözlenmektedir. Yabancı dil alanı sosyal bir 
meslek gibi görülmemesine rağmen bu bölümden mezun olanların çoğunlukla öğretmenliğe yöneldiği görülmektedir. Kadınların ilgilerinin Görsel Sanatlar alanında yüksek çıkması cinsiyetler için kalıplaşmış meslek ve etkinlik vurgusunu doğrulamaktadır. Erkeklerin lehine olan Siyasal-Mali Bilimlerin siyasal boyutu insanla çalışma gerektirse de siyaset toplum tarafından erkeğe atfedilmiş bir meslek alanıdır. Bazı alanlarda anlamlı farklılık gözlenmemesi ise literatürde mesleki ilgi açısından kadınlar ve erkekler arasında anlamlı farklılık gözlenmeyen çalışmalarla örtüşebilir. Ayrıca iletişim ve medya gibi bazı sektörler hem kadın hem de erkeklerin birlikte tercih ettiği mesleki alanlardır.

Bu araştırmada SED belirlenirken eve alınan kitap sayısı, anne-babanın sosyal etkinliğe katılma sıklığı, anne-babanın eğitim düzeyi ve gelir düzeyinden yararlanılmıştır. SED kavramı oldukça göreceli ve birçok değişkeni içinde barındıran bir kavramdır. Yapılacak olan yeni çalışmalarda SED belirlemek için farklı değişkenler de tercih edilebilir.

Araştırma sonuçları cinsiyetin meslek seçiminde ve mesleki ilgilerde önemli bir değişken olduğunu göstermektedir. Mesleki rehberlik yapan danışmanlar mesleki tercihlerde cinsiyet değişkenini dikkate almalıdır. Kadınların insanlarla çalışma gerektiren mesleklerde, erkeklerinse insanlarla çalışma gerektirmeyen özellikle nesne ağırlıklı mesleklerde daha mutlu olabileceği unutulmamalıdır.

Anahtar Sözcükler: Mesleki İloi, Mesleki Tercih, Cinsiyet ilişkisi, SED ilişkisi, Mesleki Alan Illgi Envanteri 
